\title{
Effectiveness of Mathematical Learning Devices Based on Verbal Linguistic Intelligence and Mathematical Logical Intelligence
}

\author{
Sry Rasyiidu Tebe ${ }^{1, a^{*}}$, Anwar2,b, Bahrun,c \\ 1Department of Mathematics Education, Universitas Syiah Kuala, Banda Aceh, 23111, Indonesia \\ a sryrasyiidu.sr@gmail.com; b anwarramli@unsyiah.ac.id; c bahrun@unsyiah.ac.id \\ *Corresponding Author \\ Whatsapp Number [ 085360605552 ]
}

How to Cite: Tebe, S. R., Anwar.,\& Bahrun. (2019). Effectiveness of Mathematical Learning Devices Based on Verbal Linguistic Intelligence and Mathematical Logical Intelligence. International Journal for Educational and Vocational Studies, 1(4), 304-307

\section{ARTICLE HISTORY}

Received: 11May 2019

Revised: 22 June2019

Accepted: 2 August 2019

\section{KEYWORDS}

Mathematical Learning Devices; Verbal Linguistic Intelligence; Mathematical Logical Intelligence;

\begin{abstract}
2013 curriculum has mandated the importance of teachers and paying attention to aspects of diversity of students in learning, including intelligence. Based on the type of intelligence proposed by Gardner (2003), linguistic-verbal intelligence and mathematical logical intelligence are two intelligences that need to be considered by the teacher in mathematics learning, for example when the teacher prepares a mathematics learning tool. This study aimed to determine the effectiveness of mathematical learning tools based on linguistic-verbal intelligence and mathematical logical intelligence on material equations and linear inequalities. This study used the Plomp development model which consists of three phases, namely initial investigation, design, and assessment. The trial was carried out four times for students of class VII-8 in SMP Negeri 2 Banda Aceh. To determine the effectiveness of learning devices, criteria Kemp was applied, et al (1994). The results of the development showed that the mathematics learning tools based on linguistic-verbal intelligence and mathematical logical intelligence were effective. Because of that, this learning tool is worthy of being used by teachers in mathematics learning, especially in similarities material and linear inequalities.
\end{abstract}

This is an open access article under the CC-BY-SA license.

\section{INTRODUCTION}

2013 curriculum required a teacher to compile learning tools consisting of syllabus, lesson plan (RPP), student activity sheet (LKPD) and learning outcomes test (THB). Teachers are required to consider the diversity of students in the preparation of good learning tools. One of the considerations of the teacher is student intelligence. Intelligence is important because it is the initial capital to improve students' abilities (Sarabi \& Gafoor, 2017). It can be concluded that intelligence has an important role in every learning.

Nine bits of intelligence presented by Gardner (2003), linguistic-verbal intelligence and mathematical-logical intelligence are more likely to be closely related in mathematics learning, so teachers need to consider their application in mathematics learning. That is because problems in mathematics emphasize more on problem-solving (Korkmaz, 2016). Learning mathematics requires mathematical-logical intelligence to understand and analyze problems (Latterell \& Wilson, 2016). For example, when the students are asked to solve the problem of equations and linear inequalities of one variable in the form of a story, they experienced the difficulty in understanding the problem in the story due to a lack of verbal abuse. Likewise, the students experience difficulties in modeling problems because of a lack of mathematical-logical intelligence (Novitasari, Rahman, \& Alimuddin, 2015; Sarabi \& Gafoor, 2017). Therefore, the two bits of intelligence need to get the attention of the teacher, whose application can be started from the moment the learning Device is arranged.

The teacher has not paid attention to students' intelligence in designing the learning Devices. As a result, the tools that teachers make have not led to linguistic-verbal intelligence and mathematical logical intelligence (Gracious \& Shyla, 2012; Ivaniyah \& Akbar, 2014). So far the teacher has only focused on the learning model (Wahyuni, 2017). In fact, the teacher should consider the two intelligences because it is needed in remembering information, analyzing problems, and solving mathematical problems that are absent (Nasab, 2016). Teachers should prepare their learning Devices early by paying attention to linguistic-verbal intelligence and mathematical logical intelligence, so that it can be predicted that students will easily receive the 
mathematics material given by the teacher.

The results of research by Yusna (2017) concluded that the explanations using mathematical logical intelligence can help students to develop. Rahmah (2017) added that in mathematics learning, verbal-linguistic intelligence helps students analyze routine and non-routine questions. Based on the problems above, this research was carried out in order to determine the effectiveness of mathematical learning tools based on linguistic-verbal intelligence and mathematical logical intelligence, especially on the material of equations and linear non-variable variance.

\section{MATERIALS AND METHODS}

This research is a development research using the Plomp model following three stages, initial investigation, design and assessment. This research was conducted in SMP Negeri 2 Banda Aceh and the trial subjects in this study were students of class VII-8 SMP Negeri 2 with 30 students. In this study six trials were conducted including one small group trial meeting with the subject of the trial was five students, four meetings in a large group trial with the subject of 30 students and one meeting at the test of learning outcomes. The Devices in this study were learning implementation sheets, observation sheets of student activities and formative tests. Each meeting was carried out by observing the implementation of learning, the activities of students and given a quiz at the end of each meeting.

The data obtained was analyzed and described for each meeting. This study produced a valid and practical learning device following Nieveen's criteria (1999), while effectively using the criteria Kemp, Morrison and Ross (1994). Learning Devices are said to be valid if all validators state that they are feasible to use, practically if the entire validator states that the learning Devices developed can be applied in a good category while the Device is said to be effective if four of the six indicators are met.

\section{RESULTS AND DISCUSSIONS}

The stages of development that were done included preliminary research, prototyping phase and assessment phase. The stage of preliminary research aimed to find information including problems, potentials and facilities that can be developed in research. The Devices used in the initial analysis consisted of analysis sheets of student characteristics, user analysis sheets or needs, 2013 SMP curriculum analysis sheet, learning device concept analysis sheet, literature analysis sheet and learning resources, existing tool analysis sheet and situation analysis sheet and condition. The activity which carried out at the prototyping phase was to design a linguistic-verbal intelligence-based on the learning device and mathematical logical intelligence in accordance with the results of the needs analysis at the preliminary research stage. Meanwhile, the activity in the assessment phase was to evaluate the implementation of teaching and learning in the class.

The activity carried out at the preliminary research was to obtain the information about the need of learning device and the important of developing the device. Furthermore, the learning device was designed and validated by six validator. The instrument used to validate the device was the validation sheet. The learning device was validated by experts, teachers, and peers. After the device meets valid criteria and is given a recommendation with a slight revision, the device can be used for testing. The device is said to be valid if the validator states that the device developed is based on strong theoretical and the components contained in it are related to one another. This is supported by Ivaniyah \& Akbar (2014) who stated that valid learning devices are worthy of being used for effective learning processes. The results of the validation can be seen in Table 1 .

Table 1. Results of revision of learning devices

\begin{tabular}{ll}
\hline \multicolumn{1}{c}{ Before Revision } & \multicolumn{1}{c}{ After Revision } \\
\hline Time allocation was inappropiate & Time allocation was adjusted \\
\hline Learning objectives were not clear & $\begin{array}{l}\text { Learning objectives were revised to be } \\
\text { more clearly }\end{array}$ \\
\hline Learning strategies did not look specific & $\begin{array}{l}\text { Learning strategies were stated based on } \\
\text { the learning }\end{array}$ \\
\hline $\begin{array}{l}\text { The indicators to be measured should } \\
\text { be added so that the learning } \\
\text { objectives are achieved }\end{array}$ & $\begin{array}{l}\text { Basic Competence } \\
\text { Learning activities in the introductory } \\
\text { section should be given an alternative images included alternative answers and } \\
\text { answer to the Lesson Plan, the images are appropriate in the } \\
\text { used should be images that are close } \\
\text { to everyday life }\end{array}$ \\
\hline
\end{tabular}

Furthermore, a small group trial was then conducted. In a small group trial was obtained students' responses towards the learning devices which was being developed through student response questionnaires and questionnaires on student activity sheets. The questionnaire was analyzed descriptively. The results obtained were students' activity sheets which were filled to reach an average value of 3.12 in the good category. While student responses showed a positive response to mathematics learning based on linguistic-verbal intelligence and mathematical-logical intelligence. At the time of the trial, it was found that there were difficulties in interpreting students' images on the students' activity sheet. In line with Murizal (2012), students experienced difficulties in understanding concepts, analyzing problems, and observing images related to prerequisite material.

Based on errors obtained from small group trials, a slight revision was needed due to the incompatibility found in LAS test items. Furthermore, a large group trial was conducted to see the implementation of learning using the learning tools which had been revised. Mathematical learning using linguistic-verbal intelligence-based 
learning and mathematical-logical intelligence can help students to solve problems related to story problems. Kandel (2016) added teachers play a role in controlling students during the process of implementing learning. To see the implementation of learning, it can be seen in Table 2 .

Table 2 Implementation of Learning

\begin{tabular}{|c|c|c|c|c|}
\hline Criteria & 1st Meeting & 2nd Meeting & 3rd Meeting & $\begin{array}{c}\text { 4th } \\
\text { Meeting }\end{array}$ \\
\hline $\begin{array}{l}\text { How to give } \\
\text { examples, } \\
\text { motivation, } \\
\text { learning } \\
\text { objectives to } \\
\text { students } \\
\text { after } \\
\text { learning the } \\
\text { material }\end{array}$ & $\begin{array}{l}\text { Giving } \\
\text { motivation } \\
\text { showed the } \\
\text { benefits } \\
\text { obtained by } \\
\text { students }\end{array}$ & $\begin{array}{l}\text { Was good and } \\
\text { got good } \\
\text { responses from } \\
\text { students }\end{array}$ & $\begin{array}{l}\text { Giving } \\
\text { motivation } \\
\text { showed the } \\
\text { benefits } \\
\text { obtained and } \\
\text { got good } \\
\text { responses } \\
\text { from students }\end{array}$ & $\begin{array}{l}\text { Was good } \\
\text { and } \\
\text { obtained } \\
\text { benefits by } \\
\text { the } \\
\text { students }\end{array}$ \\
\hline $\begin{array}{l}\text { Giving the } \\
\text { stressing in } \\
\text { the learning } \\
\text { steps } \\
\text { presented }\end{array}$ & $\begin{array}{l}\text { Giving the } \\
\text { stressing to } \\
\text { get feedbacks } \\
\text { from students } \\
\text { was still not } \\
\text { maximum }\end{array}$ & $\begin{array}{l}\text { The stressing } \\
\text { to get feedbacks } \\
\text { from students } \\
\text { was still less } \\
\text { maximum }\end{array}$ & $\begin{array}{l}\text { The stressing } \\
\text { to get } \\
\text { feedbacks } \\
\text { from students } \\
\text { was better }\end{array}$ & $\begin{array}{l}\text { The } \\
\text { stressing } \\
\text { to get } \\
\text { feedbacks } \\
\text { from } \\
\text { students } \\
\text { was good } \\
\text { already }\end{array}$ \\
\hline $\begin{array}{l}\text { Assistance } \\
\text { to students } \\
\text { to reflect } \\
\text { and direct } \\
\text { students in } \\
\text { evaluation }\end{array}$ & $\begin{array}{l}\text { Giving } \\
\text { assistance to } \\
\text { students to } \\
\text { make a } \\
\text { reflection and } \\
\text { evaluation } \\
\text { was good }\end{array}$ & $\begin{array}{l}\text { The assistance } \\
\text { to make } \\
\text { evaluation dan } \\
\text { reflection was } \\
\text { good }\end{array}$ & $\begin{array}{l}\text { The reflection } \\
\text { and evaluation } \\
\text { were good }\end{array}$ & $\begin{array}{l}\text { The } \\
\text { reflection } \\
\text { and } \\
\text { evaluation } \\
\text { were good } \\
\text { and } \\
\text { fullfilled }\end{array}$ \\
\hline $\begin{array}{l}\text { Suitability of } \\
\text { activities on } \\
\text { the device } \\
\text { and time } \\
\text { allocation } \\
\text { presented }\end{array}$ & $\begin{array}{l}\text { The time } \\
\text { allocation } \\
\text { used was not } \\
\text { suitable yet }\end{array}$ & $\begin{array}{l}\text { The time } \\
\text { management } \\
\text { used was } \\
\text { suitable }\end{array}$ & $\begin{array}{l}\text { The time } \\
\text { allocation was } \\
\text { suitable }\end{array}$ & $\begin{array}{l}\text { The time } \\
\text { allocation } \\
\text { was used } \\
\text { effectively }\end{array}$ \\
\hline
\end{tabular}

Based on Table 2, it was obtained that there was significant improvement in each meeting. Mathematics learning based on linguistic-verbal intelligence-based learning and mathematical-logical intelligence makes students able to analyze and understand the problems presented. This can be seen from group activities carried out during learning in which the students were enthusiastic in learning activities starting from giving the stressing to evaluation. Linguistic-verbal intelligence and mathematical-logical intelligence of students were more explored. In addition, in the trial of large groups, the implementation of the mathematics learning tools developed included in the good category with increased implementation in each meeting. Thus, the learning device meets the practical criteria. This is in line with Yorganci (2018) that stated that the learning becomes effective when the learning process is implemented well.

The next step was the assessment phase that was looking at students' activities and conducting learning outcome tests. Assessment criteria for student activities were viewed from several aspects, namely: listening to apperception and giving motivation given, observing instructions given by the teacher and ongoing learning activities, asking questions about things that have not been understood and obscurity regarding learning, gathering information from all references related to the material that is, equations and linear inequalities of one variable, associating the problem given, communicating the problem given and concluding the learning outcomes of each meeting. The following is a table of students' activity analysis.

Table 3. Results of Students' Activity Observation Analysis

\begin{tabular}{cc}
\hline Meeting & Scoring Percentage \\
\hline I & $82.2 \%$ \\
\hline II & $89.9 \%$ \\
\hline III & $90 \%$ \\
\hline IV & $91.0 \%$ \\
\hline Total average & $88.2 \%$ \\
\hline
\end{tabular}

From the results of the observation analysis of students' activities, it can be concluded that the average of student activities achivement relatively reached $82.2 \%$. It means that there is significant improvement of activity in each meeting and mathematics learning based on linguistic-verbal intelligence and mathematical-logical intelligence went well. Zebari, Aloo, \& Mohammedzadeh (2018) stated that the innovative learning device can improve student's activity during learning process.

The formative test consists of two, namely a test at the end of every four meetings in the form of a quiz consisting of one item and evaluation (learning result test) given after four meetings consisting of four items. The test was given to students aiming to see students' ability to solve problems, mastery of the material that has been studied and help to explore students' linguistic-verbal intelligence and mathematical-logical intelligence. The problem in the first meeting consisted of one single variable linear equation problem. The second meeting consisted of one question in the form of equivalent (equivalent) one variable linear equation. Then the third meeting was given one question related to the material in a single variable linear equation. At the last meeting, one question was related to making a model and completing a story question related to the material of the equation and the linear one variable inequality. The results of the formative test analysis are presented in Table 4 as follows.

Table 4. Results of Formative Test Analysis

\begin{tabular}{cccccc}
\hline $\begin{array}{c}\text { Average } \\
\text { test }\end{array}$ & 1st Quiz & 2nd Quiz & 3rd Quiz & 4th Quiz & THB \\
\hline Average & 71.3 & 73.6 & 74.1 & 74.5 & 75.5 \\
\hline
\end{tabular}

The results of the formative test score analysis in table 3 obtained an average score of 71.3 at the first meeting. At the second meeting the average score was 73.6. Then the third meeting obtained an average score of 74.1. At the fourth meeting the average score was 74.5. While the final 
evaluation results average score reached 75.5. It showed an improvement in the achievement of scores for each meeting. The last indicator to meet the effective criteria was the observer's response. The result from the observer's response during the learning process was positive towards the implementation of the learning device.

\section{CONCLUSION}

This study resulted in mathematical learning tools based on linguistic-verbal intelligence and mathematical-logical intelligence with material equations and one variable linear inequality. The devices developed met valid criteria and the results of small group trials showed that the devices can be used. In addition, the implementation of learning using mathematical learning tools based on linguistic-verbal intelligence and mathematical-logical intelligence in large group trials increased. The effectiveness of the device can be seen from the activity of students increasing at each meeting, formative tests and learning outcomes tests tend to increase, students gave positive responses, and observers gave a positive response. Based on the description above, it can be concluded that mathematics learning devices based on linguistic-verbal intelligence and mathematical-logical intelligence meet the effective criteria.

\section{REFERENCES}

Gardner, H. (2003). Multiple Intelligences kecerdasan majemuk teori dalam praktek. Batam. Interaksara.

Gracious, A. Shyla, F.L.J.A (2012). Multiple Intelligence and Digital Learning Awareness of Prospective B.Ed Teachers. Turkish Online Journal of Distance Education-TOJDE, 11(3). 112-118.

Irvaniyah, I dan Akbar, R.O (2014). Analisis kecerdasan logis matematis dan kecerdasan linguistik siswa berdasarkan jenis kelamin. EduMat, 3(1).

Kandeel, R.A.A. (2016). Multiple Intelligences Patterns of Students at King Saud University and Its Relationship with Mathematics' Achievement. Journal of Education and Learning, 5(3), 94-106

Kemp, J.E., Morrison, G.R., \& Ross, S.M. (1998). Designing Effective Instruction, (2nd Ed.). New Jersey: Prentice Hall.Yusna, D.P (2017).

Korkmaz, O. (2016). The Effect of Scratch and Lego Mindstorm Ev3-Based Programming Activities on Academic Achievement, Problem-Solving Skills and logical-mathematical thinking skills of students. Malaysian Online Journal of Educational Sciences, 4(3), 73-88.

Latterell, C.M., \& Wilson,J.L. (2016). Math like lion hunting a sleeping gazelle:preservice elementary teachers' metaphors of mathematics. European Journal of Science and Mathematics Education, 4(3), 283- 292.

Mkhize, D.R. (2017). Forming positive identities to enhace mathematics learning among adolescents. Universal Journal of Educational Research, 5(2), 175-180.

Murizal, A., Yarman, \& Yerizon. (2012). Pemahaman Konsep Matematis dan Model Pembelajaran Quantum Teaching. Jurnal Pendidikan Matematika, 1(1).
Nasab, E.F. (2016). Relationship between multiple intelligence, reading proficiency, and implementing motivational strategies: a study of Iranian secondary students. International Journal of Education \& Literacy Studies. 4(3), 34-40.

Nieveen, N. (1999). Prototyping to reach product quality. Dalam J.V.D. Akker, R. M. Branch, K. Gustafson, N. Nieveen \& T. Plomp (Eds.), Design approaches and tools in education and training, 125-135. Netherlands: Kluwer Academic Publishers.

Novitasari, D., Rahman, A., \& Alimuddin. (2015). Profil kreativitas siswa dalam pemecahan masalah matematika ditinjau dari kecerdasan visual spasial dan logis matematis pada siswa SMAN 3 Makassar. Jurnal Daya Matematis, 3(1), 41-50.

Plomp, T. (2013). Educational Design Research: A Introduction. In Educatinal Design Research.

Rahmah, E. (2017). Pengembangan perangkat pembelajaran berbasis Multiple Intelligences. Tesis. Banda Aceh: Magister Pendidikan Matematika Universitas Syiah Kuala.

Sarabi, M.K., \& Gafoor, A.K. (2017). Influence of linguistic challenges on attitude towards mathematics learning among upper primary Students of Kerala. Paper Presented in International Seminar on Priorities, Barriers, \& Directions of Education.

Yusna, D.P.S. (2018). Kecerdasan logis matematis melalui model pembelajaran berbasis proyek pada siswa SMA. Tesis. Banda Aceh: Magister Pendidikan Matematika Universitas Syiah Kuala.

Yorganci, S. (2018). The Mathematis Learning Styles of Vocational Collage Students. European Journal of Educational Research, $7(4), 935-940$.

Zebari, S.S.M., Allo, H.A.A., \& Mohammedzadeh, B. (2018). Multiple Intellegences-Based Planning of EFL Classes. Advanced in Languange and Liter 